\title{
Investigation of Global Methylation in Peripheral Blood from Breast Cancer Patients
}

Xue Cao ${ }^{1,2}$, Tim Holland-Letz ${ }^{3}$, Qiuqiong Tang ${ }^{1,2}$, Xiaomeng Li ${ }^{1,2}$, Melanie Gündert ${ }^{1,2}$, Katarina Cuk ${ }^{1,2}$, Sarah Schott ${ }^{1}$, Jörg Heil ${ }^{4}$, Michael Golatta ${ }^{4}$, Christof Sohn ${ }^{1}$, Andreas Schneeweiss ${ }^{1,5}$ and Barbara Burwinkel ${ }^{1,2 *}$

${ }^{1}$ Department of Gynecology and Obstetrics, Molecular Biology of Breast Cancer, University of Heidelberg, Heidelberg, Germany

${ }^{2}$ Division of Molecular Epidemiology (C080), German Cancer Research Center (DKFZ), Heidelberg, Germany

${ }^{3}$ Department of Biostatistics (C060), German Cancer Research Center (DKFZ), Heidelberg, Germany

${ }^{4}$ Department of Gynecology and Obstetrics, University Women's Clinic, Heidelberg, Germany

${ }^{5}$ National Centre for Tumor Diseases, Heidelberg, Germany

\begin{abstract}
Breast cancer is the most frequent malignancy with high mortality among woman around the world. Global DNA methylation has been investigated by multiple studies and suggested as a screening biomarker for cancer. DNA methylation for two repetitive elements, LINE1 and Alu, was investigated in whole blood DNA from 229 breast cancer patients and 151 controls by using MassARRAY EpiTyper assay. Results showed that the mean methylation level of investigated $C P G$ sites of $L I N E 1$ in peripheral blood from breast cancer patients was lower than that in controls ( $\mathrm{P}=8.78 \mathrm{E}-06)$, especially for one specific $\mathrm{CpG}$ site (LINE1 CpG 1 with $\mathrm{P}=3.64 \mathrm{E}-10)$. ROC curve analysis of LINE1_CpG_1 methylation and LINE1 mean methylation was used to estimate the potential clinical utility of LINE1 methylation, area under the curve (AUC) was 0.73 (95\% confidence interval $(\mathrm{Cl}): 0.68-0.79)$ and $0.68(95 \% \mathrm{Cl}$ : 0.62-0.74), respectively. In addition, the highest increased risk was observed in the lowest quartile of LINE1_CpG_1 methylation and LINE1 mean methylation (odds ratio $(\mathrm{OR})=38.47$ and $5.94 ; 95 \% \mathrm{Cl}: 8.77-168.64$ and $2.94-11 . \overline{98}$; $\mathrm{P}$ for trend=1.42E-07 and 1.33E-05 respectively). For Alu, significant hypomethylation of Alu_CpG_13 and Alu CpG_14 in peripheral blood of breast cancer cases compared to controls was observed $(P=0.002$ and $\bar{P}=0.006)$. For the combined analysis, the AUC of the 10 most important CpG sites of LINE1 and Alu is 0.77 (95\% Cl: 0.72-0.83). Our study indicates that hypomethylation of specific $\mathrm{CpG}$ sites in LINE1 and Alu elements in peripheral blood DNA could be potential biomarkers for breast cancer risk. Further multicenter prospective studies are needed to verify these results.
\end{abstract}

Keywords: Breast cancer; DNA methylation; LINE1; Alu

Abbreviations: BC: Breast Cancer; ROC: Receiver Oprating Characteristic; OR: Odds Ratio; AUC: Area Under the Curve; IQR: Interquartile Range; CI: Confidence Interval; 450K: Infinium Human Methylation450 Bead Chip array; 5-mdC: 5-Methyldeoxycytosine

\section{Introduction}

Breast cancer $(\mathrm{BC})$ is one of the most common cancers and the leading cause of cancer death among women in the worldwide. Although screening mammography is critical for the declined mortality of breast cancer, the limitations of mammography are well recognized, especially for young women with a high mammographic density of breasts $[1,2]$. Therefore, other approaches are urgently needed for breast cancer early detection.

DNA methylation is a type of epigenetic alterations which plays an important role in cancer development [3]. Promoter hypermethylation of tumor suppressor genes and global hypomethylation leading to malignancy have been studied extensively in different cancer types [4]. Global DNA hypomethylation is a hallmark of most cancers [5-9], including breast cancer [10-14]. This DNA hypomethylation has been proposed to activate oncogenes [15,16], induce genomic instability [17] and promote chromosome instability [7,18-21].

Genome-wide DNA hypomethylation originates from the decrease of 5-methyldeoxycytosine (5-mdC) in dinucleotide CpG sites throughout the genome. As most $5-\mathrm{mdC}$ sites are rich in repetitive sequences that account for approximately half of the human genome and those repetitive DNA sequences are highly methylated in normal cells $[7,22,23]$. There are several different categories of repetitive sequences dispersed throughout the genome, such as long interspersed nuclear elements, short interspersed nuclear elements and satellite repeats. LINE1, a long interspersed nuclear element, is scattered throughout about $17 \%$ of the entire genome [24,25]. Alu is a short interspersed repetitive sequence that contributes almost $11 \%$ of the human genome [26]. Some studies found that the loss of DNA methylation for elements LINE1, Alu and Sat2 has been observed in cancer cells [22,27].

The DNA methylation of repetitive elements has been associated with global DNA methylation used as a biomarker for global methylation status by some investigators [28]. Furthermore, global hypomethylation in peripheral blood DNA has been considered as a risk factor for many tumors, such as colorectal, bladder and head and neck cancer [29-32].

In this study, we examined the methylation status of LINE1 and $A l u$ in whole blood DNA of breast cancer cases and controls by using MassARRAY Epityper assay in order to find a potential blood-based biomarker for $\mathrm{BC}$ detection.

*Corresponding author: Barbara Burwinkel, Department of Gynecology and Obstetrics, Molecular Biology of Breast Cancer, University of Heidelberg Heidelberg, Germany, Tel: +49 622156 8400; Fax: +49 622156 5356; E-mail: B.Burwinkel@dkfz-heidelberg.de

Received September 24, 2017; Accepted October 04, 2017; Published October 06 , 2017

Citation: Cao X, Holland-Letz T, Tang Q, Li X, Gündert M, et al. (2017) Investigation of Global Methylation in Peripheral Blood from Breast Cancer Patients. J Mol Biomark Diagn S2: 037. doi:10.4172/2155-9929.S2-037

Copyright: (c) 2017 Cao X, et al. This is an open-access article distributed under the terms of the Creative Commons Attribution License, which permits unrestricted use, distribution, and reproduction in any medium, provided the original author and source are credited 


\section{Materials and Methods}

\section{Study population}

Our study was approved by the Ethics Committee of the University Hospital in Heidelberg. All samples of BC cases and healthy controls were Caucasian and obtained from the same region in southwest Germany. All enrolled patients and controls have given informed consent. Blood samples of sporadic BC patients are from the Genome study in our research group and were collected at the time-point of diagnosis before any treatment at University Hospital of Heidelberg. Clinical parameters of $\mathrm{BC}$ patients were confirmed according to the American Joint Committee on Cancer staging manual [33]. Detailed characteristics of BC cases are shown in Supplementary Table S1. Additionally, control blood samples come from our biomarker study, which were obtained from blood donors by the university hospital of Heidelberg. All the controls were healthy when donating blood and no one had a family history of BC. All blood samples were collected during the period from 2011 to 2014 . A total of 229 sporadic BC cancer patients and 151 healthy controls were randomly selected for this study (Table 1).

\section{DNA isolation and bisulfite conversion}

DNA from whole blood samples $(200 \mu \mathrm{l})$ was extracted by using QIAamp DNA Blood Mini Kit (Qiagen, Hilden, Germany) according to the manufacturer's recommendations. DNA quality and quantity were measured by the NanoDrop ND-1000 UV/Vis-Spectralphotometer 3.3 (peqLab, Erlangen, Germany). Aliquots of DNA (500 ng) were bisulfite-treated with the EZ-96 DNA methylation Gold kit (Zymo Research Corporation, Orange, USA) according as the description of the manufacturer.

\section{Primer design and PCR amplification}

The online tool, "epidesigner" (http://www.epidesigner.com/start3. html), was used for the primer design. The PCR primers for LINE1 and $A l u$ and their amplicon sequences were shown in Supplementary Tables S2. PCR reaction was performed in a total volume of $6 \mu$ l. PCR reaction components included $10 \mathrm{ng} / \mu \mathrm{l}$ bisulfite-treated DNA, $10 \times$ CoralLoad Buffer(Qiagen), $10 \mathrm{mM}$ dNTPs, $1 \mu \mathrm{M}$ of each (forward and reverse) primer (Sigma), and $5 \mathrm{U}$ HotStar Taq DNA polymerase (Qiagen, Valencia CA). The touch-down PCR profile was $95^{\circ} \mathrm{C}$ for 5 minutes, denaturation at $94^{\circ} \mathrm{C}$ for 30 seconds, primer annealing from $59^{\circ} \mathrm{C}$ to $53^{\circ} \mathrm{C}$ for 30 seconds, a final extension at $72^{\circ} \mathrm{C}$ for 1 minute, then $72^{\circ} \mathrm{C}$ for 5 minutes, $4^{\circ} \mathrm{C}$ for infinite. $1 \%$ agarose gel was used for electrophoresis to inspect PCR products and visualized under ultraviolet light.

\section{Methylation analysis}

The Sequenom MassARRAY EpiTyper assay was used for methylation analysis as described previously [34]. The PCR products were dealt with succeeding procedures according as the protocol of Sequenom MassARRAY EpiTyper Assay and cleaned by Resin. Then 8-15 $\mathrm{nl}$ of cleavage reaction was transferred to a 384 SpectroCHIP by using the Nanodispenser (SEQUENOM). The chip was analyzed with the MassARRAY (SEQUENOM). The mass spectra were collected from

\begin{tabular}{|c|c|c|c|c|}
\hline Gene & Sample Types & Group & Number & Age $(y)$ Mean \pm SD \\
\hline \multirow{2}{*}{ LINE1 } & \multirow{2}{*}{$\begin{array}{c}\text { Peripheral blood } \\
\text { DNA }\end{array}$} & Sporadic BC cases & 229 & $48.31 \pm 8.09$ \\
\hline & & Controls & 151 & $41.47 \pm 10.91$ \\
\hline \multirow{2}{*}{ Alu } & \multirow{2}{*}{$\begin{array}{c}\text { Peripheral blood } \\
\text { DNA }\end{array}$} & Sporadic BC cases & 229 & $48.31 \pm 8.09$ \\
\hline & & Controls & 151 & $41.47 \pm 10.91$ \\
\hline
\end{tabular}

\begin{tabular}{|c|c|c|c|c|}
\hline CpG site & $\begin{array}{l}\text { BC Cases median } \\
\text { (IQR), } n=227\end{array}$ & $\begin{array}{l}\text { Controls median } \\
\text { (IQR), } n=151\end{array}$ & P value ${ }^{a}$ & $\begin{array}{l}\text { Adjusted } \\
\text { P value }^{\text {b }}\end{array}$ \\
\hline LINE1_CpG_1 & $0.76(0.74-0.79)$ & $0.80(0.76-0.82)$ & 4.04E-11 & $3.64 \mathrm{E}-10$ \\
\hline LINE1_CpG_2 & $0.92(0.91-0.94)$ & $0.93(0.91-0.94)$ & 0.143 & 0.057 \\
\hline LINE1_CpG_3,4,5 & $0.88(0.86-0.89)$ & $0.88(0.87-0.90)$ & 0.001 & 0.002 \\
\hline LINE1_CpG_9 & $0.87(0.86-0.88)$ & $0.88(0.87-0.90)$ & 4.71E-04 & 0.001 \\
\hline LINE1_CpG_12 & $0.71(0.69-0.74)$ & $0.74(0.71-0.77)$ & 1.21E-07 & 4.09E-07 \\
\hline LINE1_CpG_14 & $0.90(0.89-0.91)$ & $0.91(0.90-0.92)$ & 3.94E-09 & 8.19E-09 \\
\hline LINE1_CpG_15 & $0.94(0.78-0.98)$ & $0.90(0.80-0.98)$ & 0.416 & 0.927 \\
\hline $\begin{array}{l}\text { LINE1_- } \\
\text { CpG_16,17 }\end{array}$ & $0.88(0.90-0.91)$ & $0.88(0.90-0.91)$ & 0.056 & 0.199 \\
\hline Mean & $0.85(0.84-0.86)$ & $0.86(0.85-0.88)$ & 2.14E-06 & 8.78E-06 \\
\hline
\end{tabular}

Abbreviations: IQR: Interquartile Range

aP value for the difference between controls and patients was analyzed by MannWhitney $\mathrm{U}$ test and adjusted by Bonferroni-Holm method $\alpha=0.00556$; ${ }^{\text {b }} \mathrm{P}$ value was calculated by logistic regression and adjusted by age. Significant $P$ values are in Bold $(\mathrm{P}<0.05)$.

Table 2: Comparison of DNA methylation in LINE1 amplicon between breast cancer patients and controls in peripheral blood.

a MassARRAY Compact MALDI-TOF (SEQUENOM) and spectra's methylation ratios were generated by MassARRAY EpiTyper v1.0 software. Results were expressed as "beta" values between 0 and 1.

\section{Statistical analysis}

Statistical analysis was performed with SPSS statistics 24.0 and R 3.4.0. The nonparametric Mann-Whitney $\mathrm{U}$ test and Kruskal-Wallis $\mathrm{H}$ test were used for all univariable comparisons. Multivariable logistic regression models were calculated to evaluate the association between LINE1 and Alu methylation and breast cancer risk. For this, the methylation level of one or more CpG sites was entered either as a raw beta value, or categorized into four quartile groups based on the distribution among controls. In all cases age was included as a covariable. Receiver operating characteristic (ROC) curves were used to display sensitivity and specificity and the corresponding area under the curve (AUC) was calculated using the R package "pROC". To account for overfitting, additional corrected estimates of the AUC were calculated using the " $0.632+$ " bootstrap technique (R package "Daim"). Variable selection models were calculated using the "step AIC" function from the R package "Mass". The significance level for all analyses was set as $\mathrm{P}<0.05$

\section{Results}

\section{Hypomethylation of repetitive elements in $\mathrm{BC}$ patients}

LINE1: DNA methylation levels in two repetitive elements, LINE1 and $\mathrm{Alu}$, were compared in $229 \mathrm{BC}$ patients and 151 healthy controls. $11 \mathrm{CpG}$ sites were measured in the amplicon of LINE1 (Table 2). We observed significant hypomethylation of seven CpG sites, LINE1_ CpG_1, LINE1_CpG_3,4,5, LINE1_CpG_9, LINE1_CpG_12, LINE1_ CpG_14, in peripheral blood of BC patients. Their median methylation levels, interquartile ranges (IQRs) and the $\mathrm{P}$ values were shown in Table 2. The mean methylation level of all investigated CpG sites of LINE1 was also significantly lower in peripheral blood of $\mathrm{BC}$ cases than that in healthy controls (median of mean methylation level in $\mathrm{BC}$ cases $=0.85$ (IQR=0.84-0.86) compared to controls 0.86 (IQR=0.85-0.88), with adjusted $\mathrm{P}=8.78 \mathrm{E}-06)$.

In Figure 1, the methylation levels of the seven significant $\mathrm{CpG}$ sites of LINE1 were plotted for the BC cases and controls. Although all of these CpG sites revealed significant results, the methylation levels of cases and controls were quite similar. The biggest difference was shown in the median methylation levels between BC cases and controls for 
Citation: Cao X, Holland-Letz T, Tang Q, Li X, Gündert M, et al. (2017) Investigation of Global Methylation in Peripheral Blood from Breast Cancer Patients. J Mol Biomark Diagn S2: 037. doi:10.4172/2155-9929.S2-037

Page 3 of 8

LINE1_CpG_1 (median methylation level in $\mathrm{BC}$ cases $=0.76$ (IQR $=0.74$ 0.79) compared to controls 0.80 ( $\mathrm{IQR}=0.76-0.82$ ), with adjusted $\mathrm{P}=3.64 \mathrm{E}-10$ ) and LINE1_CpG_12 (median methylation level in BC cases $=0.71 \quad(\mathrm{IQR}=0.69-0.74)$ compared to controls 0.74 (IQR=0.710.77), with adjusted $\mathrm{P}=4.09 \mathrm{E}-07)$. The lowest $\mathrm{P}$ value was observed for LINE1_CpG_1 with adjusted $\mathrm{P}=3.64 \mathrm{E}-10$ (Table 2). As especially LINE1_CpG_1 showed a strong association with BC, we also calculated the diagnostic AUC for this single CpG site through a ROC analysis.

ROC curve analysis of LINE1_CPG_1 methylation and LINE1 mean methylation (Figure 2) was used to estimate the potential clinical

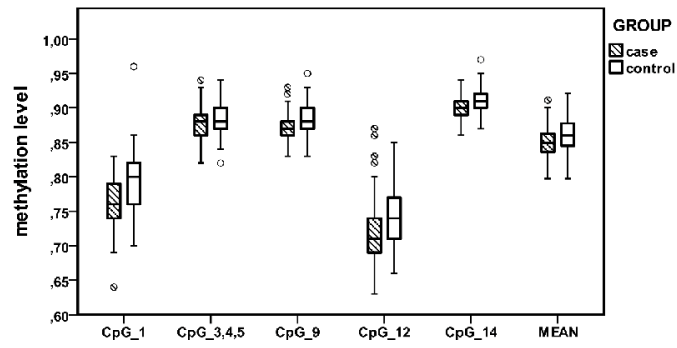

Figure 1: Box plot showing the different methylation levels of $B C$ cases and controls for single $\mathrm{CpG}$ sites within LINE1.
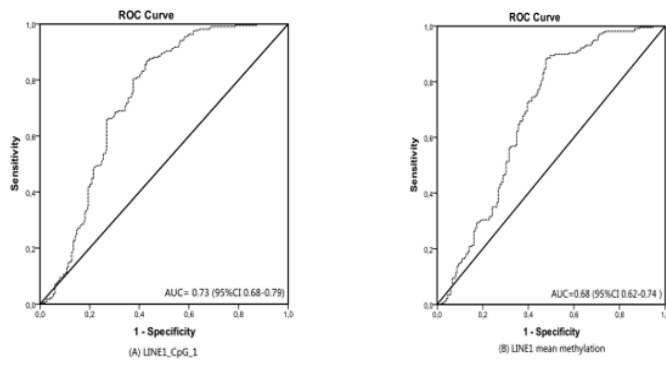

Figure 2: ROC curve of LINE1_CPG_1 methylation (A) and LINE1 mean methylation (B). The ROC curve was calculated by logistic regression.

\begin{tabular}{|c|c|c|c|c|c|}
\hline Quartile & $\begin{array}{c}\text { LINE1_CpG_1 } \\
\text { methylation }\end{array}$ & $\begin{array}{c}\text { case, } \\
\mathbf{n = 2 2 9}\end{array}$ & $\begin{array}{c}\text { control, } \\
\mathbf{n = 1 5 1}\end{array}$ & OR (95\% CI) & $\mathbf{P}^{*}$ value \\
\hline 1 & $0.64-0.76$ & 122 & 44 & $38.47(8.77-168.64)$ & $\mathbf{1 . 3 0 E - 0 6}$ \\
\hline 2 & $0.77-0.80$ & 81 & 44 & $24.84(5.64-109.37)$ & $\mathbf{2 . 1 6 E}-05$ \\
\hline 3 & $0.81-0.82$ & 22 & 32 & $10.27(2.21-47.68)$ & $\mathbf{2 . 9 3 E - 0 3}$ \\
\hline 4 & $0.83-0.96$ & 2 & 31 & 1.00 (reference) & - \\
\hline \multicolumn{7}{r}{ P for trend* } & $\mathbf{1 . 4 2 E - 0 7}$ \\
\hline
\end{tabular}

Note: ${ }^{*} p$ value and $p$ for trend were calculated by logistic regression and adjusted for age. Significant $p$ values are in bold $\alpha=0.05$.

Table 3: Associations between quartile of LINE1_CpG_1 methylation and the risk of breast cancer.

\begin{tabular}{|c|c|c|c|c|c|}
\hline Quartile & $\begin{array}{l}\text { LINE1 mean } \\
\text { methylation }\end{array}$ & $\begin{array}{l}\text { case, } \\
n=229\end{array}$ & $\begin{array}{c}\text { control, } \\
n=151\end{array}$ & OR $(95 \% \mathrm{Cl})$ & $P^{*}$ value \\
\hline 1 & $0.798-0.845$ & 100 & 41 & $\begin{array}{c}5.94(2.94- \\
11.98)\end{array}$ & $6.54 \mathrm{E}-07$ \\
\hline 2 & $0.846-0.860$ & 60 & 35 & $\begin{array}{l}4.44(2.13- \\
9.28)\end{array}$ & 7.35E-05 \\
\hline 3 & $0.861-0.877$ & 52 & 32 & $\begin{array}{c}3.90(1.84- \\
8.24)\end{array}$ & 3.66E-04 \\
\hline 4 & $0.878-0.921$ & 15 & 43 & \multicolumn{2}{|c|}{1.00 (reference) } \\
\hline \multicolumn{5}{|c|}{$P$ for trend ${ }^{*}$} & 1.33E-05 \\
\hline
\end{tabular}

Note: * $p$ value and $p$ for trend were calculated by logistic regression and adjusted for age. Significant $p$ values are in bold $\alpha=0.05$.

Table 4: Associations between quartile of LINE1 mean methylation and the risk of breast cancer.

\begin{tabular}{|c|c|c|c|c|c|c|}
\hline CpG site & $\begin{array}{c}\text { Case, } \\
\text { n }\end{array}$ & $\begin{array}{c}\text { Control, } \\
n\end{array}$ & $\begin{array}{c}\text { BC Cases } \\
\text { median } \\
(\text { IQR) }\end{array}$ & $\begin{array}{c}\text { Controls } \\
\text { median } \\
(I Q R)\end{array}$ & $\begin{array}{c}P \\
\text { value }^{a}\end{array}$ & $\begin{array}{l}\text { Adjusted } \\
\text { P value }^{\mathbf{b}}\end{array}$ \\
\hline Alu_CpG_1,2 & 229 & 150 & $\begin{array}{c}0.21(0.19- \\
0.23)\end{array}$ & $\begin{array}{c}0.21(0.20- \\
0.23)\end{array}$ & 0.348 & 0.208 \\
\hline Alu_CpG_3 & 229 & 150 & $\begin{array}{c}0.63(0.62- \\
0.64)\end{array}$ & $\begin{array}{c}0.63(0.62- \\
0.64)\end{array}$ & 0.193 & 0.131 \\
\hline Alu_CpG_7 & 212 & 125 & $\begin{array}{c}0.46(0.44- \\
0.47)\end{array}$ & $\begin{array}{c}0.46(0.44- \\
0.47)\end{array}$ & 1.0 & 0.252 \\
\hline$\stackrel{\text { Alu }}{\text { CpG_11,12 }}$ & 229 & 148 & $\begin{array}{c}0.53(0.52- \\
0.55)\end{array}$ & $\begin{array}{c}0.53(0.52- \\
0.55)\end{array}$ & 1.0 & 0.345 \\
\hline Alu_CpG_13 & 229 & 149 & $\begin{array}{c}0.63(0.62- \\
0.65)\end{array}$ & $\begin{array}{c}0.65(0.62- \\
0.67)\end{array}$ & 0.002 & 0.002 \\
\hline Alu_CpG_14 & 229 & 147 & $\begin{array}{l}0.50(0.48- \\
0.55)\end{array}$ & $\begin{array}{c}0.54(0.49- \\
0.56)\end{array}$ & 0.035 & 0.006 \\
\hline Alu_- & 157 & 88 & $\begin{array}{c}0.65(0.63- \\
0.67)\end{array}$ & $\begin{array}{c}0.66(0.63- \\
0.68)\end{array}$ & 0.348 & 0.128 \\
\hline Mean & 229 & 150 & $\begin{array}{c}0.51(0.50- \\
0.53)\end{array}$ & $\begin{array}{c}0.52(0.50- \\
0.53)\end{array}$ & 0.348 & 0.343 \\
\hline
\end{tabular}

Abbreviations: IQR: Interquartile Range OR: Odds Ratio

aP value for the difference between controls and patients was analyzed by MannWhitney $U$ test and adjusted by Bonferroni-Holm method $\alpha=0.00625$; ${ }^{b} P$ value was calculated by logistic regression and adjusted by age. Significant $P$ values are in Bold $(\mathrm{P}<0.05)$.

Table 5: Comparison of DNA methylation in Alu amplion between breast cancer patients and controls in peripheral blood.

\begin{tabular}{|c|c|c|c|c|c|}
\hline Quartile & $\begin{array}{c}\text { Alu_CpG_13 } \\
\text { methylation }\end{array}$ & $\begin{array}{c}\text { case, } \\
\mathbf{n = 2 2 9}\end{array}$ & $\begin{array}{c}\text { control, } \\
\mathbf{n = 1 5 1}\end{array}$ & OR (95\% Cl) * & $\mathbf{P}^{*}$ value \\
\hline 1 & $0.57-0.62$ & 92 & 41 & $2.50(1.25-5.02)$ & $\mathbf{0 . 0 1}$ \\
\hline 2 & $0.63-0.65$ & 87 & 45 & $2.10(1.05-4.19)$ & $\mathbf{0 . 0 4}$ \\
\hline 3 & $0.66-0.67$ & 27 & 37 & $0.87(0.40-1.88)$ & 0.72 \\
\hline 4 & $0.68-0.73$ & 23 & 26 & 1.00 (reference) & - \\
\hline \multicolumn{5}{|c|}{ P for trend } \\
\hline
\end{tabular}

Note: * $p$ value and $p$ for trend were calculated by logistic regression and adjusted for age. Significant $p$ values are in bold $\alpha=0.05$.

Table 6: Associations between quartile of Alu_CpG 13 methylation and the risk of breast cancer.

utility of LINE1 methylation, AUC was 0.73 (95\% CI: $0.68-0.79)$ and 0.68 (95\% CI: 0.62-0.74) respectively.

Moreover, in the quartile analysis we observed that patients in the lowest methylation quartile of LINE1_CpG_1 have the highest OR value of 38.47 (95\% CI: 8.77-168.64) compared to the highest quartile. P for trend was 1.42E-07 for LINE1_CpG_1 methylation in Table 3.

Similarly, as shown in Table 4, an increased risk was found in the lower quartiles compared to the highest quartile of LINE1 mean methylation $(\mathrm{OR}=5.94,4.44$ and $3.90 ; 95 \% \mathrm{CI}=2.94-11.98,2.13-9.28$ and 1.84-8.24 respectively; $\mathrm{P}$ for trend=1.33E-05).

Alu: For Alu, we investigated $11 \mathrm{CpG}$ sites in the amplicon and found a significant difference in methylation of Alu_CpG_13 and Alu_CpG_14 in peripheral blood between cases and controls (Table 5) with adjusted $\mathrm{P}=0.002$ and 0.006 respectively (median of methylation level for Alu_CpG_13=0.63 in cases (IQR=0.62-0.65) compared to controls 0.65 (IQR=0.62-0.67) and median of methylation level for Alu_CpG_14=0.50 (IQR=0.48-0.55) in cases compared to controls 0.54 (IQR=0.49-0.56)). All other investigated $\mathrm{CpG}$ sites did not show significant differences between $\mathrm{BC}$ cases and controls. The box plot and ROC curve of $A l u \_C p G \_13$ and $A l u \_C p G \_14$ were shown in Supplementary Figures 1 and 2 respectively with AUC $=0.67$ (95\% CI: 0.61-0.74) and 0.67 (95\% CI: 0.61-0.73).

In addition, as shown in Table 6, we found an increased risk in the first two lower quartiles compared with the highest quartile of the 


\begin{tabular}{|c|c|c|c|c|}
\hline Cpg site & $\begin{array}{c}\text { BC Cases } \\
\text { median (IQR), } \\
n=220\end{array}$ & $\begin{array}{c}\text { Controls } \\
\text { median (IQR) } \\
n=145\end{array}$ & OR $(95 \% \mathrm{Cl})$ & P value* \\
\hline Alu_CpG_1,2 & $0.21(0.19-0.23)$ & $0.21(0.20-0.23)$ & $0.19(0.06-0.61)$ & 0.005 \\
\hline Alu_CpG_11,12 & $0.53(0.52-0.55)$ & $0.53(0.52-0.55)$ & $\begin{array}{c}13.91(2.76- \\
70.00)\end{array}$ & 0.001 \\
\hline Alu_CpG_14 & $0.50(0.48-0.55)$ & $0.54(0.49-0.56)$ & $\begin{array}{c}4.18(1.60- \\
10.96)\end{array}$ & 0.004 \\
\hline LINE1_CpG_1 & $0.76(0.74-0.79)$ & $0.80(0.76-0.82)$ & $0.04(0.01-0.15)$ & 1.33E-06 \\
\hline LINE1_CpG_2 & $0.92(0.91-0.94)$ & $0.93(0.91-0.94)$ & $\begin{array}{c}4.96(1.12- \\
21.87)\end{array}$ & 0.035 \\
\hline LINE1_CpG_14 & $0.90(0.89-0.91)$ & $0.91(0.90-0.92)$ & $\begin{array}{c}0.01(0.001- \\
0.17)\end{array}$ & 0.001 \\
\hline $\begin{array}{c}\text { LINE1_- } \\
\text { CpG_16,17 }\end{array}$ & $0.88(0.90-0.91)$ & $0.88(0.90-0.91)$ & $1.60(1.0-1.05)$ & 0.051 \\
\hline
\end{tabular}

Abbreviations: IQR: Interquartile Range OR: Odds Ratio

* $p$ values are calculated by multiple logistic regression and adjusted for age. Significant $p$ values are in bold.

Table 7: Combination analysis of LINE1 and Alu.

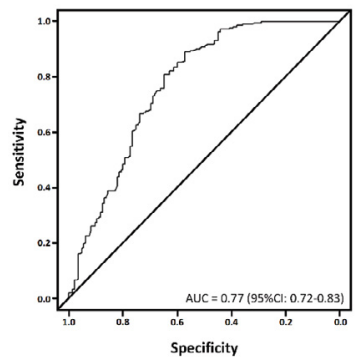

Figure 3: ROC curve of $10 \mathrm{CpG}$ sites combined by $\mathrm{CpG}$ sites of LINE1 and Alu. The ROC curve was calculated by multiple logistic regression.

methylation in Alu_CpG_13 (OR=2.50 and 2.10; 95\% CI: $1.25-5.02$ and 1.05-4.19 respectively; $P$ for trend=0.002). Contrarily, as shown in Supplementary Tables S3 and S4, no increased risk was found between the lower quartiles and the highest quartile of $A l u \_C p G \_14$ methylation with $P$ for trend $=0.08$.

\section{Combination}

Finally, we did a multiple logistic regression analysis including all CpG sites from both repetitive elements plus age (Supplementary Table S5). For this calculation, Alu_CpG_7 and Alu_CpG_15,16,17 were excluded because of the large number of missing values. Both of these CpGs were not noticeable in the univariate analysis. Again, LINE1_CpG _1 was dominant, but different other CpGs contributed additional information. Furthermore, the effect of $A l u \_C p G \_13$ was no longer significant. Performing a ROC analysis on this model, an AUC of 0.78 (95\% CI: 0.72-0.83) was observed (Supplementary Figure 3). The "0.632+" corrected AUC was 0.74 .

If only the two most promising univariate candidates LINE1_CpG_1 and Alu_CpG_13 plus age were included (Supplementary Table S6), Alu_CpG_13 still lost significance and an AUC of 0.73 (95\% CI: 0.68-0.79, corrected AUC $=0.73$ ) was observed (Supplementary Figure 4).

We also calculated a model with the 10 most important $\mathrm{CpG}$ sites plus age (Table 7). The AUC was 0.77 (95\% CI=0.72-0.83, CrossValidation AUC $=0.75$ ) (Figure 3).

\section{Correlation of LINE1 and Alu methylation with clinical characteristics of $\mathrm{BC}$ patients}

We evaluated the association of the methylation levels of these two repetitive elements with clinical features of breast cancer patients. Overall, there were no significant associations between the methylation levels of most CpG sites in LINE1 and Alu and the different clinical characteristics. Further studies are needed to discover the association between blood DNA methylation and clinicopathological parameters (Supplementary Tables S7 and S8).

\section{Comparison of the results from this study with the results of Infinium Human Methylation450 BeadChip array and with literature}

As the methylation level of repetitive elements is thought to reflect the average methylation level of genomic DNA, we compared the mean methylation of LINE1 and Alu in Sequenom MassARRAY EpiTyper data with the mean of all the $\mathrm{CpG}$ sites in $450 \mathrm{~K}$ methylation array. In the epigenome-wide $450 \mathrm{~K}$ methylation data, we observed the mean methylation level was lower in peripheral blood of patients compared to controls but the $\mathrm{P}$ value was not statistically significant $(0.523 \pm 0.28$ and $0.524 \pm 0.24$ for cases and controls, respectively, $\mathrm{P}=0.09$ (Table 8). In our here presented study, the mean methylation level of LINE1 was significantly lower in peripheral blood DNA of BC cases than that in controls (median of mean methylation level in $\mathrm{BC}$ cases $=0.85$ (IQR $=0.84$ 0.86) compared to controls 0.86 ( $\mathrm{IQR}=0.85-0.88$ ), with $\mathrm{P}=2.14 \mathrm{E}-06$ ). However, the mean methylation of Alu did not show a significant difference between BC patients and healthy controls (Table 8).

\section{Discussion}

In this study, we found statistically significant LINE1 hypomethylation in the peripheral blood DNA of sporadic breast cancer patients compared with healthy controls, especially for LINE1_CpG_1. We identified LINE1_CpG_1 methylation to be strongly associated with breast cancer. For $A l u$, we observed that one single CpG sites was significantly hypomethylated in the peripheral blood DNA from breast cancer cases compared to controls. Furthermore, our results showed that the decreased methylation level of LINE1_CpG_1 was associated with an increased breast cancer risk. Similar to the discovery studied by DeRoo et al, quartiles of LINE1 methylation levels were associated with the risk of breast cancer, with an increased risk observed in the lowest quartile compared with those in the highest quartile [35].

However, other studies found that there were no significant differences in the methylation levels of LINE1 and Alu in peripheral blood DNA between breast cancer cases and healthy controls, measured by different detection methods including pyrosequencing, methyLight and COBRA assays [36-41]. But some studies assessed LINE1 in only a small sample size with the number of cases smaller than $50[38,40]$. Partly in contrast to our observations, Wu et al. reported that there was no association between breast cancer risk and LINE-1 and Alu methylation [41]. Even though as mentioned in our previous review [42], LINE1 as a surrogate for global DNA methylation level might be limited, it is difficult to make a comparison among studies because of the multiple experimental assays, various study designs, different sample sizes, distinct blood fractions and lack of an agreed standard for global methylation measurement. Although the results are inconclusive, studies have provided some clues for investigating global methylation in blood DNA. Our study contributes to a growing literature showing global hypomethylation in peripheral blood DNA of breast cancer cases compared with controls.

One possible concern is that methylation status may be cell type specific. However, one study did not find a significant difference in LINE1 measurements between purified granulocyte and lymphocyte 
Citation: Cao X, Holland-Letz T, Tang Q, Li X, Gündert M, et al. (2017) Investigation of Global Methylation in Peripheral Blood from Breast Cancer Patients. J Mol Biomark Diagn S2: 037. doi:10.4172/2155-9929.S2-037

Page 5 of 8

\begin{tabular}{|c|c|c|c|c|c|c|c|c|c|c|c|c|c|c|c|}
\hline \multirow[b]{2}{*}{ Gene } & \multirow[b]{2}{*}{ Author, year } & \multicolumn{4}{|c|}{ Literature\# } & & \multicolumn{4}{|c|}{$450 \mathrm{~K}$ results } & & \multicolumn{4}{|c|}{ Sequenom Mass ARRAY Epityper assay } \\
\hline & & $\begin{array}{c}\text { BC Cases } \\
\text { No./ Controls } \\
\text { No. }\end{array}$ & $\begin{array}{c}\text { Meth } \\
(\%) \\
\text { (cases) }\end{array}$ & $\begin{array}{c}\text { Meth (\%) } \\
\text { (controls) }\end{array}$ & $\begin{array}{c}P \\
\text { value }\end{array}$ & & $\begin{array}{c}\text { BC CASES } \\
\text { No.l } \\
\text { Controls } \\
\text { No. }\end{array}$ & $\begin{array}{c}\text { Cases } \\
\text { Mean+- } \\
\text { SD }\end{array}$ & $\begin{array}{c}\text { controls } \\
\text { Mean+- } \\
\text { SD }\end{array}$ & $\stackrel{P}{\text { value* }^{*}}$ & & $\begin{array}{c}\text { BC Cases } \\
\text { No.l } \\
\text { Controls } \\
\text { No. }\end{array}$ & $\begin{array}{l}\text { Case } \\
\text { Median } \\
\text { (IQR) }\end{array}$ & $\begin{array}{l}\text { controls } \\
\text { Median } \\
(\text { IQR) }\end{array}$ & $\begin{array}{c}P \\
\text { value* }^{*}\end{array}$ \\
\hline \multirow{11}{*}{$\begin{array}{c}\text { LINE } \\
1\end{array}$} & $\begin{array}{c}\text { Kitkunmthom } \\
{[40]}\end{array}$ & $36 / 144$ & 40 & 42 & $>0.05$ & MEAN & $48 / 48$ & $\begin{array}{c}0.523+- \\
0.28\end{array}$ & $\begin{array}{c}0.524+- \\
0.24\end{array}$ & 0.09 & LINE 1 & $229 / 151$ & $\begin{array}{c}0.85 \\
(0.84- \\
0.86)\end{array}$ & $\begin{array}{c}0.86(0.85- \\
0.88)\end{array}$ & $\begin{array}{c}8.78 \mathrm{E}- \\
06\end{array}$ \\
\hline & $\mathrm{Xu}[38]$ & $1064 / 1100$ & 78.8 & 78.8 & 0.94 & - & - & - & - & - & MEAN & - & - & - & - \\
\hline & Brennan [37] & - & - & - & - & - & - & - & - & - & & & & & \\
\hline & BGS cohort & $241 / 242$ & $\begin{array}{c}79.0 \\
(78.1- \\
79.9)\end{array}$ & $\begin{array}{c}79.0(77.9- \\
80.1)\end{array}$ & 0.96 & - & - & - & - & - & - & - & - & - & - \\
\hline & EPIC cohort & $232 / 263$ & $\begin{array}{c}75.1 \\
(73.9- \\
76.3) \\
\end{array}$ & $\begin{array}{c}75.1(73.9- \\
76.3)\end{array}$ & 0.89 & - & - & - & - & - & - & - & - & - & - \\
\hline & $\begin{array}{l}\text { KConFab } \\
\text { cohort }\end{array}$ & $153 / 218$ & $\begin{array}{c}76.6 \\
(75.2- \\
77.6)\end{array}$ & $\begin{array}{c}76.0(74.3- \\
78.0)\end{array}$ & 0.2 & - & - & - & - & - & - & - & - & - & - \\
\hline & Wu [42] & - & - & - & - & - & - & - & - & - & - & - & - & - & - \\
\hline & MethyLight & $265 / 333$ & $\begin{array}{c}107.4+- \\
63.6\end{array}$ & $\begin{array}{c}108.5+- \\
59.1\end{array}$ & $>0.05$ & - & - & - & - & - & - & - & - & - & - \\
\hline & $\begin{array}{l}\text { pyrose } \\
\text { quencing } \\
\text { (mean) }\end{array}$ & $279 / 340$ & $\begin{array}{c}74.5^{+-} \\
3.0\end{array}$ & $74.5+-2.6$ & $>0.05$ & - & - & - & - & - & - & - & - & - & - \\
\hline & Cho [41] & $40 / 40$ & 70 & 78 & $>0.05$ & - & - & - & - & - & - & - & - & - & - \\
\hline & Choi [39] & $19 / 18$ & 74.7 & 73.9 & 0.176 & - & - & - & - & - & - & - & - & - & - \\
\hline \multirow[t]{2}{*}{ Alu } & Wu [42] & $266 / 334$ & $\begin{array}{c}95.5+- \\
36.5\end{array}$ & $98.7+-51.5$ & $>0.05$ & - & - & - & - & - & Alu & $229 / 151$ & $\begin{array}{c}0.51 \\
(0.50- \\
0.53)\end{array}$ & $\begin{array}{c}0.52(0.50- \\
0.53)\end{array}$ & 0.343 \\
\hline & Cho [41] & $40 / 40$ & 58 & 61 & $>0.05$ & - & - & - & - & - & MEAN & - & - & - & - \\
\hline
\end{tabular}

Note: * $P$ value was calculated by logistic regression and adjusted by age. Significant $P$ values are in bold $(P<0.05)$; $\#$ literature based on review by Tang et al. in 2016

Table 8: Comparison of LINE1 and Alu methylation levels between different analysis methods.

samples [43]. Generally, peripheral blood samples from epidemiological studies always comprise mixed cell populations, and it is not feasible or practical for fractionation of cell populations in an epidemiological study setting [37].

\section{Conclusion and Limitations}

Our study had some potential limitations. Many factors such as lifestyle, environmental exposures $[44,45]$ and even genetic susceptibility can affect methylation signatures. In one study, LINE1 methylation in leukocyte DNA was lower in persons who smoked blond tobacco than nonsmokers and was inversely associated with arsenic toenail concentration [43]. These factors were not investigated in our study and should be taken into account in future studies. In addition, we did not investigate the whole CpG sites of LINE1 and Alu, which may not completely reflect LINE1 and Alu methylation. Finally, the differences of every investigated CpG sites in LINE1 and Alu amplicons between BC cases and controls are very small, thus larger study cohorts including multicenter prospective studies are needed to validate these results.

In summary, this study indicates that hypomethylation of specific CpG sites in Alu and especially in LINE1 elements in peripheral blood DNA may be the potential biomarkers for breast cancer risk.

\section{Acknowledgement}

We thank Sabine Serick and Yanxiang Jiang for their technical support. This study was supported by the German Cancer Research Center (DKFZ) and University Women's Clinic, Heidelberg. Xue Cao was financed by the China Scholarship Council (CSC).

\section{References}

1. Elmore JG, Barton MB, Moceri VM, Polk S, Arena PJ, et al. (1998) Ten-year risk of false positive screening mammograms and clinical breast examinations. $\mathrm{N}$ Engl J Med 338: 1089-1096.
2. Alagaratnam TT, Wong J (1985) Limitations of mammography in Chinese females. Clin Radiol 36: 175-177.

3. Jones PA, Baylin SB (2002) The fundamental role of epigenetic events in cancer. Nat Rev Genet 3: 415-428.

4. Mutirangura A (2007) Quantitative PCR analysis for methylation level of genome: Clinical implications in cancer. Asian Biomedicine 1: 121-128.

5. Wilson AS, Power BE, Molloy PL (2007) DNA hypomethylation and human diseases. Biochim Biophys Acta 1775: 138-162.

6. Dunn BK (2003) Hypomethylation: One side of a larger picture. Ann NY Acad Sci 983: 28-42.

7. Ehrlich M (2002) DNA methylation in cancer: Too much, but also too little. Oncogene 21: 5400-5413.

8. Feinberg AP, Ohlsson R, Henikoff S (2006) The epigenetic progenitor origin of human cancer. Nat Rev Genet 7: 21-33.

9. Feinberg AP, Tycko B (2004) The history of cancer epigenetics. Nat Rev Cancer 4: 143-153.

10. Soares J, Pinto AE, Cunha CV, André S, Barão I, et al. (1999) Global DNA hypomethylation in breast carcinoma: Correlation with prognostic factors and tumor progression. Cancer 85: 112-118.

11. Bernardino J, Roux C, Almeida A, Vogt N, Gibaud A, et al. (1997) DNA hypomethylation in breast cancer: An independent parameter of tumor progression? Cancer Genet Cytogenet 97: 83-89.

12. Gama-Sosa MA, Slagel VA, Trewyn RW, Oxenhandler R, Kuo KC, et al. (1983) The 5-methylcytosine content of DNA from human tumors. Nucleic Acids Res 11: $6883-6894$

13. Jackson K, Yu MC, Arakawa K, Fiala E, Youn B, et al. (2004) DNA hypomethylation is prevalent even in low-grade breast cancers. Cancer Bio Ther 3: 1225-1231.

14. Esteller M, Fraga MF, Guo M, Garcia-Foncillas J, Hedenfalk I, et al. (2001) DNA methylation patterns in hereditary human cancers mimic sporadic tumorigenesis. Hum Mol Genet 10: 3001-3007. 
Citation: Cao X, Holland-Letz T, Tang Q, Li X, Gündert M, et al. (2017) Investigation of Global Methylation in Peripheral Blood from Breast Cancer Patients. J Mol Biomark Diagn S2: 037. doi:10.4172/2155-9929.S2-037

15. Feinberg AP, Vogelstein B (1983) Hypomethylation distinguishes genes of some human cancers from their normal counterparts. Nature 301: 89-92.

16. Holliday R, Pugh JE (1975) DNA modification mechanisms and gene activity during development. Science 187: 226-32.

17. Gaudet F, Hodgson JG, Eden A, Jackson-Grusby L, Dausman J, et al. (2003) Induction of tumors in mice by genomic hypomethylation. Science 300: 489492.

18. Robertson KD (2001) DNA methylation, methyltransferases, and cancer Oncogene 20: 3139-3155.

19. Clark SJ, Melki J (2002) DNA methylation and gene silencing in cancer: Which is the guilty party? Oncogene $21: 5380-5387$

20. Karpf AR, Matsui S (2005) Genetic disruption of cytosine DNA methyltransferase enzymes induces chromosomal instability in human cancer cells. Cancer Res 65: 8635-8639

21. Frühwald MC, Plass C (2002) Global and gene-specific methylation patterns in cancer: Aspects of tumor biology and clinical potential. Mol Genet Metab 75: $1-16$

22. Hoffmann MJ, Schulz WA (2005) Causes and consequences of DNA hypomethylation in human cancer. Biochem Cell Biol 83: 296-321.

23. Prak ET, Kazazian HH Jr. (2000) Mobile elements and the human genome. Nat Rev Genet 1: 134-144.

24. Kazazian HH Jr., Moran JV (1998) The impact of L1 retrotransposons on the human genome. Nat Genet 19: 19-24.

25. Lander ES, Linton LM, Birren B, Nusbaum C, Zody MC, et al. (2001) Initial sequencing and analysis of the human genome. Nature 409: 860-921.

26. Deininger P (2011) Alu elements: Know the SINEs. Genome Biol 12: 236.

27. Yoder JA, Walsh CP, Bestor TH (1997) Cytosine methylation and the ecology of intragenomic parasites. Trends Genet 13: 335-340.

28. Weisenberger DJ, Campan M, Long TI, Kim M, Woods C, et al. (2005) Analysis of repetitive element DNA methylation by MethyLight. Nucleic Acids Res 33: $6823-6836$.

29. Lim U, Flood A, Choi SW, Albanes D, Cross AJ, et al. (2008) Genomic methylation of leukocyte DNA in relation to colorectal adenoma among asymptomatic women. Gastroenterology 134: 47-55.

30. Moore LE, Pfeiffer RM, Poscablo C, Real FX, Kogevinas M, et al. (2008) Genomic DNA hypomethylation as a biomarker for bladder cancer susceptibility in the Spanish Bladder Cancer Study: a case-control study. Lancet Oncol 9: 359-366.

31. Hsiung DT, Marsit CJ, Houseman EA, Eddy K, Furniss CS, et al. (2007) Global DNA methylation level in whole blood as a biomarker in head and neck squamous cell carcinoma. Cancer Epidemiol Biomarkers Prev 16: 108-114.
32. Pufulete M, Al-Ghnaniem R, Leather AJ, Appleby P, Gout S, et al. (2003) Folate status, genomic DNA hypomethylation, and risk of colorectal adenoma and cancer: A case control study. Gastroenterology 124: 1240-1248.

33. Edge SB, Compton CC (2010) The American Joint Committee on Cancer: The 7th edition of the AJCC cancer staging manual and the future of TNM. Ann Surg Oncol 17: 1471-1474.

34. Tang Q, Holland-Letz T, Slynko A, Cuk K, Marme F, et al. (2016) DNA methylation array analysis identifies breast cancer associated RPTOR, MGRN1 and RAPSN hypomethylation in peripheral blood DNA. Oncotarget 7: 64191-64202.

35. Deroo LA, Bolick SC, Xu Z, Umbach DM, Shore D, et al. (2014) Global DNA methylation and one-carbon metabolism gene polymorphisms and the risk of breast cancer in the Sister Study. Carcinogenesis 35: 333-338.

36. Brennan K, Garcia-Closas M, Orr N, Fletcher O, Jones M, et al. (2012) Intragenic ATM methylation in peripheral blood DNA as a biomarker of breast cancer risk. Cancer Res 72: 2304-2313.

37. Xu X, Gammon MD, Hernandez-Vargas H, Herceg Z, Wetmur JG, et al. (2012) DNA methylation in peripheral blood measured by LUMA is associated with breast cancer in a population-based study. Faseb J 26: 2657-2666.

38. Choi JY, James SR, Link PA, McCann SE, Hong CC, et al. (2009) Association between global DNA hypomethylation in leukocytes and risk of breast cancer. Carcinogenesis 30: 1889-1897.

39. Kitkumthorn N, Tuangsintanakul T, Rattanatanyong P, Tiwawech D, Mutirangura A (2012) LINE-1 methylation in the peripheral blood mononuclear cells of cancer patients. Clin Chim Acta 413: 869-874.

40. Cho YH, Yazici H, Wu HC, Terry MB, Gonzalez K, et al. (2010) Aberrant promoter hypermethylation and genomic hypomethylation in tumor, adjacent normal tissues and blood from breast cancer patients. Anticancer Res 30 : 2489-2496.

41. Wu HC, Delgado-Cruzata L, Flom JD, Perrin M, Liao Y, et al. (2012) Repetitive element DNA methylation levels in white blood cell DNA from sisters discordant for breast cancer from the New York site of the Breast Cancer Family Registry. Carcinogenesis 33: 1946-1952.

42. Tang Q, Cheng J, Cao X, Surowy H, Burwinkel B (2016) Blood-based DNA methylation as biomarker for breast cancer: A systematic review. Clin Epigenetics 8: 115

43. Tajuddin SM, Amaral AF, Fernández AF, Rodríguez-Rodero S, Rodríguez RM, et al. (2013) Genetic and non-genetic predictors of LINE-1 methylation in leukocyte DNA. Environ Health Perspect 121: 650-656.

44. Christensen BC, Houseman EA, Marsit CJ, Zheng S, Wrensch MR, et al. (2009) Aging and environmental exposures alter tissue-specific DNA methylation dependent upon CpG island context. PLoS Genet 5: e1000602.

45. Teschendorff AE, Menon U, Gentry-Maharaj A, Ramus SJ, Weisenberger DJ, et al. (2010) Age-dependent DNA methylation of genes that are suppressed in stem cells is a hallmark of cancer. Genome Res 20: 440-446. 